\title{
Molecular data support the existence of four main lineages in the phylogeny of the family Eulophidae (Hymenoptera)
}

\author{
Молекумярные данные подтверждают существование четырех \\ основных ветвей в филогенезе семейства Eulophidae \\ (Hymenoptera)
}

\author{
A.V. Gumovsky \\ A.В. Гумовский \\ I.I. Schmalhausen Institute of Zoology, National Academy of Sciences of Ukraine, 15 Bogdan Khmelnitsky St., Kiev-30 01601, Ukraine. \\ E-mail: gumovsky@izan.kiev.ua, entedon@gmail.com \\ Институт зоологии им. И.И. Шмальгаузена НАН Украины, ул. Б. Хмельницкого, 15, Киев, 01601, Украина.
}

KEY WORDS: Hymenoptera, Eulophidae, Tetracampidae, Trichogrammatidae, nuclear genes, mitochondrial genes, phylogeny, morphology.

КЛЮЧЕВЫЕ СЛОВА: Hуmenoptera, Eulophidae, Tetracampidae, Trichogrammatidae, ядерные гены, митохондриальные гены, филогения, морфология.

ABSTRACT. This study is an attempt to infer the relationships between Eulophidae and putatively related families, as well as major groups within eulophids, with the combined analysis of nuclear (28S D2 rDNA) and two mitochondrial sequences (cytochrome oxidase subunit I, COI, and cytochrome b, Cyt b). There is no signal of close relationships between the families Eulophidae, Tetracampidae and Trichogrammatidae, but at least Eulophidae and Trichogrammatidae are supported as monophyletic. The Eulophidae lineage consists of four internal lineages corresponding to the recognized subfamilies: Eulophinae, Tetrastichinae, Entedoninae and Entiinae (= Euderinae). Morphology of the subfamilies (including putative synapomorphies) is also discussed.

РЕЗЮМЕ. Данное исследование представляет собой попытку выяснить филогенетические связи между семейством Eulophidae и предположительно родственными ему семействами, а также между основными группами внутри собственно эвлофид, исходя из анализа ядерной (28S D2 rDNA) и двух митохондриальных [субъединица I оксидазы цитохрома (COI) и цитохром b (Cyt b)] последовательностей ДНК. Не удалось обнаружить свидетельств тесного родства семейств Eulophidae, Tetracampidae и Trichogrammatidae, однако по крайней мере Eulophidae и Trichogrammatidae являются монофилетическими. Собственно ветвь Eulophidae состоит из четырех внутренних ветвей, соответствующих традиционно рассматриваемым подсемействам: Eulo- phinae, Tetrastichinae, Entedoninae и Entiinae (= Euderinae). В статье также обсуждаются морфологические особенности подсемейств эвлофид, включая предполагаемые синапоморфии.

\section{Introduction}

The family Eulophidae is the most speciose in the family Chalcidoidea and it has an extremely wide host range [Noyes, 2004]. Eulophids are one of the most successful groups of insects involved in biocontrol worldwide (e.g. [Murphy, La Salle, 1999; Waterhouse, Norris, 1987]). Therefore taxonomy and phylogeny of those parasitoids attract attention of numerous researchers. The first signal of monophyly of Eulophidae was obtained by Campbell et al. [2000] on the basis of $28 \mathrm{~S}$ D2 rDNA gene of chalcidoids. Also, Elasmus Westwood, 1833, the only genus of the former family Elasmidae, appeared to be a derived taxon within Eulophidae. Then Gauthier et al. [2000] used the same gene on broader sampling to clarify the phylogeny of Eulophidae. Those authors supported the idea that Elasmidae are derived eulophids, demonstrated that the subfamilies Eulophinae and Tetrastichinae are closely related and provided some new characters to support monophyly of some groups of Eulophidae. Gumovsky [2002] also used the same gene for studying the subfamily Entedoninae and discussed distribution of some morphological characters within eulophids*.

The families Eulophidae, Tetracampidae, Trichogrammatidae and also Aphelinidae are sometimes considered as the "eulophid lineage" [Gibson et al., 1997].

* Note added in proof. When the present paper had already been in press, another paper on Eulophidae phylogeny [Burks et al., 2011] was published online (doi: 10.1111/j.1096-0031.2011.00358.x). The results presented in the latter work are in general agreement with the phylogenetic pattern demonstrated in the present paper. However, more detailed discussion could not be included in this paper due to technical reasons. 
This group is characterized by the reduced number of antennal (generally 4-7, but occasionally more) and tarsal segments (3-4). However, there are many overlaps in distribution of these character states within the "eulophid lineage", as well as with certain outgroups. For instance, only the males of some Tetracampidae have 4-segmented tarsi, whereas the females have 5segmented tarsi likewise most other Chalcidoidea. Gladun and Gumovsky [2006] demonstrated that the representatives of the "eulophid lineage" share similar morphology of pretarsus (e.g. number of proximal setae on manubrium reduced to 2-3 setae). However, there were some overlaps with other families (Mymaridae, Pteromalidae) and high probability of convergence of this character in unrelated groups. Gokhman [2004, 2009] and then Gokhman and Gumovsky [2009] suggested that Eulophidae belong to the so-called «lownumbered» chalcidoid families with the modal haploid number of chromosomes $\mathrm{n}=6$ (but with occasional modifications to 5 or 8 ), whereas $\mathrm{n}=9-12$ in many other families. However, karyotypes of that kind also occur outside Eulophidae [Gokhman, 2009]. On the other hand, the chromosome numbers reduced independently in various groups of Chalcidoidea [Gokhman, Gumovsky, 2009].

The monophyly of Eulophidae and the relationships of this family with other groups of the "eulophid lineage" therefore requires further studies and verification based on additional data.

The main purposes of the present study are:

(1) Independent reconstructions of phylogeny of Eulophidae and presumably related groups based on original data matrix of nuclear (28S D2 rDNA, used by Gauthier et al. [2000]) and mitochondrial gene sequences (cytochrome b gene and cytochrome oxidase subunit 1 gene).

(2) A review of morphological features of the monophyletic taxa within Eulophidae.

\section{Materials and methods}

\section{Materials}

Eulophidae are traditionally considered as consisting of four subfamilies, Eulophinae, Entedoninae, Tetrastichinae and Entiinae (= Euderinae [Hansson, Straka, 2009]). Some other groups, namely, Ophelimini, Anselemellini, Keryini and Platytetracampini have been regarded eulophids (e.g., Bouček [1988]), but then were treated as "unplaced groups" or even noneulophids by Gauthier et al. [2000]. In this study we focused only on the representatives of the four traditionally recognized subfamilies (Table 1), keeping in mind that their relationships with the "unplaced groups" require a separate study based on excessive sampling of those taxa.

\section{DNA studies}

DNA extraction and sequencing were conducted in the Molecular Systematics Laboratory of the Entomol- ogy Department of the Natural History Museum (BMNH, London, UK). Single specimen of each species was used for DNA extraction and further sequencing. Genomic DNA was extracted from the ethanolpreserved individuals using a protocol largely based on those described in the DNeasy Tissue Handbook provided by Qiagen (Hilden, Germany). We amplified partial sequences of the nuclear 28S D2 rDNA, mitochondrial cytochrome oxidase subunit I (COI) and mitochondrial cytochrome $\mathrm{b}(\mathrm{Cyt} \mathrm{b})$ genes for all studied samples, using the following primers:

(a) 28S D1 and D2 rDNA (nuclear): D1F (ACCC GCTGAATT TAAGCATAT) [Harry et al., 1996] and D2R (TTGG TCCGTGTTTCAAGACGG) [Campbell et al., 1993].

(b) Cytochrome oxidase I mtDNA (mitochondrial, COI): COI-Jerry (CAACATTTATTTTGATTTTTT GG) and COI-2613 (ATTGCAAATACTGCACCTAT) [Simon et al., 1994].

(c) Cytochrome b mtDNA (mitochondrial, Cytb): CB3 (GAGGAGCAACTGTAATTACTAA) and CB4 (AAAAGAAA(AG)TATCATTCAGGTTGAAT) [Pons, 2006].

Standard polymerase chain reactions (PCR) were carried out in $25 \mathrm{~mL}$ reaction mixtures consisting of $2.5 \mathrm{~mL}$ BioTaq 4xNH4 Buffer, $2.625 \mathrm{~mL} 25 \mathrm{mM}$ $\mathrm{MgCl}_{2}, 0.7 \mathrm{~mL} \mathrm{dNTP}, 0.35 \mathrm{~mL}$ primers, $0.084 \mathrm{~mL}$ BioTaq Taq polymerase and 1 to $4 \mathrm{~mL}$ DNA. The total volume was increased up to $25 \mathrm{~mL}$ by adding of the necessary volume of distilled water. DNA fragments were sequenced in one direction (with a reverse primer).

\section{Sequence alignment and matrix composition}

Only original sequences of the all three genes were used for the analysis. The sequences were obtained for 45 taxa (32 of Eulophidae, 13 of other families, Appendix 1). The obtained sequences were aligned using the ClustalW algorithm [Thompson et al., 1994] in BioEdit software version 5.0.0 [Hall, 1999] with default settings and corrected manually if certain ambiguities were found. The obtained sequences were deposited in the GenBank with corresponding accession numbers (JF816057-JF816191).

The matrices were prepared for each gene separately in BioEdit. 28S D2 matrix was represented by 648 positions after alignment, Cyt $\mathrm{b}$ matrix was represented by 341 positions and COI matrix was represented by 397 positions. These three alignments were combined into a single matrix of total 1386 positions, which was eventually used for the analyses.

\section{Phylogeny reconstructions}

Phylogenies were reconstructed with three different approaches:

(1) The maximum parsimony analysis. This analysis was executed with PAUP* version 4.0b10 [Swofford, 1998], using default options for heuristic search and treating gaps as missing data, unweighted and unordered characters. Of total 1386 characters in the 
Table. Main characteristics of the recognized subfamilies of Eulophidae. Таблица. Основные особенности подсемейств эвлофид, принимаемых в статье.

\begin{tabular}{|c|c|c|}
\hline Subfamily & $\begin{array}{l}\text { Characters (newly proposed ones are marked with asterisk* }{ }^{*} \text {, putative } \\
\text { synapomorphies underlined) }\end{array}$ & Hosts and biology \\
\hline Eulophinae & $\begin{array}{l}\text { Calcar evenly acute*; basitarsal comb oblique*; transition between } \\
\text { subcosta of submarginal vein and parastigma mostly smooth, subcosta } \\
\text { bears } 3 \text { or more setae on its dorsal side; postmarginal vein longer than } \\
\text { stigmal one; male scape without defined sensory area; anterior margin of } \\
\text { clypeus straight; prothoracic spiracle exposed; propleurae closely } \\
\text { convergent (except for tribe Cirrospilini); scutellum with two pairs of } \\
\text { setae, rarely with submedian and sublateral grooves (if it is, e.g. in } \\
\text { Stenopetius Bouček, 1988, submedian groove incomplete and sublateral } \\
\text { one curved); 7th and 8th gastral terga of female fused together into } \\
\text { syntergum. }\end{array}$ & $\begin{array}{l}\text { Mostly idio-/ koinobiont } \\
\text { ectoparasitoids of larvae of } \\
\text { Lepidoptera, Coleoptera and } \\
\text { Hymenoptera, idiobiont } \\
\text { endoparasitoids mostly attack } \\
\text { pupae and eggs, but their } \\
\text { immature stages are not } \\
\text { studied well enough; rarely } \\
\text { hyperparasitoids (Dimmockia } \\
\text { Ashmead, 1904). }\end{array}$ \\
\hline $\begin{array}{l}\text { Tetrasti- } \\
\text { chinae }\end{array}$ & $\begin{array}{l}\text { Calcar evenly acute (bifid in Aprostocetus and Crataepus, aberrantly } \\
\text { widened in latter genus)*; basitarsal comb oblique*, subcosta of } \\
\text { submarginal vein with a break in place of contact with parastigma, } \\
\text { subcosta bears } 1-3 \text { setae on its dorsal side; postmarginal vein apparently } \\
\text { reduced; sensory area of male scape restricted to a narrow plaque at } \\
\text { ventral margin (except for e.g. Melittobia); anterior margin of clypeus } \\
\text { bilobed } \\
\text { with two prothoracic spiracle exposed; propleurae divergent; scutellum } \\
\text { grooves; 7th and 8th gastral terga of female fused together into } \\
\text { syntergum. }\end{array}$ & $\begin{array}{l}\text { Idio-/koinobiont ecto- } \\
\text { /endoparasitoids of immature } \\
\text { stages of insects as well as of } \\
\text { spider eggs and } \\
\text { mite/nematode galls; } \\
\text { hyperparasitoids are common. } \\
\text { Some genera (Leptocybe } \\
\text { Fisher et LaSalle, 2004, } \\
\text { Quadrastichodella Girault, } \\
\text { 1922 etc.) are phytophagous } \\
\text { (gallers and seed eaters). }\end{array}$ \\
\hline Entiinae & $\begin{array}{l}\text { Calcar bifid*; basitarsal comb oblique*; subcosta of submarginal vein } \\
\text { with a break in place of contact with parastigma, subcosta bears } 1-3 \\
\text { setae on its dorsal side; postmarginal vein about as long as stigmal one; } \\
\text { male scape without defined sensory area; prothoracic spiracle exposed; } \\
\text { propleurae divergent; anterior margin of clypeus emarginate (concave); } \\
\text { scutellum with two pairs of setae, generally without submedian or } \\
\text { sublateral grooves; proximal parts of } 7 \text { th and 8th gastral terga of female } \\
\text { separated from each other. }\end{array}$ & $\begin{array}{l}\text { Idiobiont ectoparasitoids of } \\
\text { beetle larvae associated with } \\
\text { polypore fungi and dead } \\
\text { wood, as well as with } \\
\text { lepidopteran larvae } \\
\text { (biological data are rather } \\
\text { limited); occasionally as } \\
\text { hyperparasitoids. }\end{array}$ \\
\hline Entedoninae & $\begin{array}{l}\text { Calcar bifid*; basitarsal comb reduced; subcosta of submarginal vein } \\
\text { with a break in place of contact with parastigma (except for e.g. } \\
\text { Eprhopalotus Girault, 1916), subcosta usually bears } 2 \text { setae on its dorsal } \\
\text { side (except for e.g. aberrant specimens of Entedon with } 3 \text { or } 4 \text { setae); } \\
\text { prothoracic spiracle concealed; propleurae divergent; male scape with } \\
\text { sensory area restricted to a narrow row stretching along ventral margin } \\
\text { (except for e.g. Euderomphale and Parzaommomyia); scutellum with one } \\
\text { pair of setae (except for e.g. Euderomphale and genera with excessive } \\
\text { scutellar pubescence, like Alachua Schauff et Boucek, 1987, Podkova } \\
\text { Gumovsky et Bouček, 2003, Dasyomphale LaSalle et Schauff, 1994, } \\
\text { etc.), rarely with submedian and sublateral grooves (if it is, e.g. in } \\
\text { Derostenus Westwood, 1833), submedian groove incomplete and } \\
\text { sublateral one curved); anterior margin of clypeus mostly straight, but } \\
\text { emarginate (concave) in Euderomphale and allied genera; } 7 \text { th and 8th } \\
\text { gastral terga of female fused together into syntergum. }\end{array}$ & $\begin{array}{l}\text { Egg, larval (often egg-larval) } \\
\text { and pupal koino-/idiobiont } \\
\text { endoparasitoids of many } \\
\text { insects (mostly Lepidoptera, } \\
\text { Coleoptera and Diptera); } \\
\text { often as hyperparasitoids. }\end{array}$ \\
\hline
\end{tabular}

combined data matrix, 521 characters were parsimonyinformative, 195 variable characters were parsimonyuninformative and 670 characters were constant. A bootstrap analysis (100 replicates using TBR branch swapping) was carried out using PAUP* to establish levels of branch support for the clades obtained.

(2) The maximum likelihood analysis. This analysis was executed using the programs jModeltest 0.1.1 [Posada, 2008] and PAUP* version 4.0b10. The matrix was first analyzed by jModeltest using default settings. The program has chosen the $G T R+G$ model as the best-fit for the matrix as a result of AICc (Akaike
Information Criteria) analysis. The PAUP* block was generated and embedded into the matrix, which was then analyzed in PAUP* with optimality criterion switched to "likelihood". A bootstrap analysis (100 replicates using TBR branch swapping) was carried out to establish levels of branch support.

(3) The Bayesian analysis. The Bayesian inference of phylogeny was analyzed with MrBayes 3 program [Ronquist, Huelsenbeck, 2003]. The evolutionary model was set to the GTR with gamma-distributed rate variation (as suggested by jModeltest) and the analysis was run until the average standard deviation of split fre- 
quencies has fallen below 0.01. Because of controversial nature of the Bayesian posterior probabilities [Douady et al., 2003] a bootstrap analysis (100 replicates using TBR branch swapping) of the tree produced by the Bayesian analysis, was done.

The resulting trees were viewed and stored with TREEVIEW program [Page, 1996] with further edition in standard graphics processing programs.

\section{Scanning electron microscopy (SEM)}

SEM was conducted in the Max-Planck Institute for Metal Research, Stuttgart (MPI), Zoologische Staatssammlung München (ZSM) and in the M.G. Kholodny Institute of Botany of the National Academy of Sciences of Ukraine (IBK, Kiev). The ethanol-preserved insects were dehydrated first in $100 \%$ ethanol and then in $100 \%$ molecular-sieved ethanol. After dehydration the specimens were critical-point dried using Polaron E3000 series apparatus. The dried specimens were transferred to SEM pin type stubs and coated with gold-palladium (MPI) or gold (ZSM, IBK) with coating thickness of about $300-500 \AA$, and examined using LEO 1530VP scanning electron microscope.

\section{Results and discussion}

\section{Phylogeny reconstructions}

The maximum parsimony analysis (MP) yielded eight most parsimonious trees after 192931 rearrangements, with the length of the best tree 3291. Then the characters were reweighted by the maximum value of retention indices, to enhance resolution. As a result, 461 characters gained weight other than 1, and when heuristic search was completed, the analysis yielded a single tree, which is shown on Fig. 1. The heuristic search under optimality criterion set to "likelihood" (ML) yielded another single tree after 24022 rearrangements (Fig. 2). The tree resulting from Bayesian analysis (BA) is shown on Fig. 3.

The trees were rooted with an outgroup taxon, Polynema sp. (Mymaridae), since Mymaridae are usually treated as a sister group to the rest of Chalcidoidea [Gibson, 1986, 1999; Gibson et al., 1999; Campbell et al., 2000; Desjardins et al., 2007]. All trees are evidently congruent in their overall topology, and differ only in minor pattern details within the main clades.

\section{Eulophidae and other groups}

Eulophidae are monophyletic in all obtained trees (Figs 1-3), and this monophyly has moderate (88\% in MP, Fig. 1) or rather high support (95\% in ML, Fig. 2). Relationships of Eulophidae with representatives of the other families included in the analysis are weakly supported, and thus remain obscure.

The monophyly of some families, namely, Encyrtidae and Trichogrammatidae, was strongly supported $(100 \%$ in all trees, Figs $1-3)$, although they were represented by just a few genera. The support of relationships between Cerapterocerus Westwood, 1833 and
Cheiloneurus Westwood, 1833 within Encyrtidae and monophyly of Poropoea Förster, 1851 and Prestwichia Lubbock, 1863 within Trichogrammatidae was notably high (100\% in all trees).

\section{Relationships within Eulophidae}

All the analyses support subdivision of Eulophidae into four main clades, corresponding to the conventional subdivision into the subfamilies: Eulophinae, Entedoninae, Tetrastichinae and Entiinae (= Euderinae) (Figs 1-3). In the analyses conducted, the recognized subfamilies are supported as monophyletic to a varying extent. The monophyly of Entiinae has the highest bootstrap support in all trees $(100 \%, 100 \%$ and $94 \%$ in MP, ML and BA trees respectively), the monophyly of Eulophinae and Tetrastichinae is strongly supported in MP and ML trees (93\% and 94\% respectively, Figs 1-3).

The subfamily Entedoninae appears as a sister group to the rest of eulophid subfamilies in all trees, although those relationships are not significantly supported.

Within Entedoninae, monophyly of the genera Entedon Dalman, 1820 (100, 95 and 94\% in MP, ML and BA trees respectively), Chrysocharis Förster, 1856 (100\% in both trees), and of two species of Pediobius Walker, 1846 (100, 85 and 95\% in MP, ML and BA trees respectively, Figs 1-3) is highly supported. Within Tetrastichinae, sister-group relationship between Pronotalia Gradwell, 1957 and Crataepus Förster, 1856 was highly supported in all trees (Figs 1-3). No clade gained essential support within Eulophinae; however, the genus Elasmus appeared to be a derived taxon within Eulophinae, thus supporting the results obtained by Campbell et al. [2000] and Gauthier et al. [2000].

\section{Morphological review}

Although Eulophidae appeared monophyletic in the obtained trees, as well as in the studies by other authors [Campbell et al., 2000; Gauthier et al., 2000], no uniquely derived morphological character supporting monophyly of this family has been found so far. Eulophidae are traditionally characterized by a combination of the following characters [Noyes, 2004]: foretibial spur (calcar) short and straight; tarsi 4-segmented (very rarely 3-segmented) in both sexes; antenna (excluding anelli) 7- to 9-segmented, with at most 4 funicular segments; gaster with a distinct petiole so that there is a distinct narrowing between the propodeum and gaster (the latter character differentiates eulophids from species of Trichogrammatidae, Aphelinidae and Signiphoridae).

A brief discussion on some key characters distinguishing the whole family Eulophidae and its subfamilies is given below. The characters distinguishing the subfamilies of Eulophidae are summarized in the Table.

\section{Legs}

Tarsi. The vast majority of the Eulophidae have 4segmented tarsi of all legs in both sexes (Fig. 4A). However, 3-segmented tarsi of all legs are reported as a diagnostic character for the entedonine genus Trisec- 


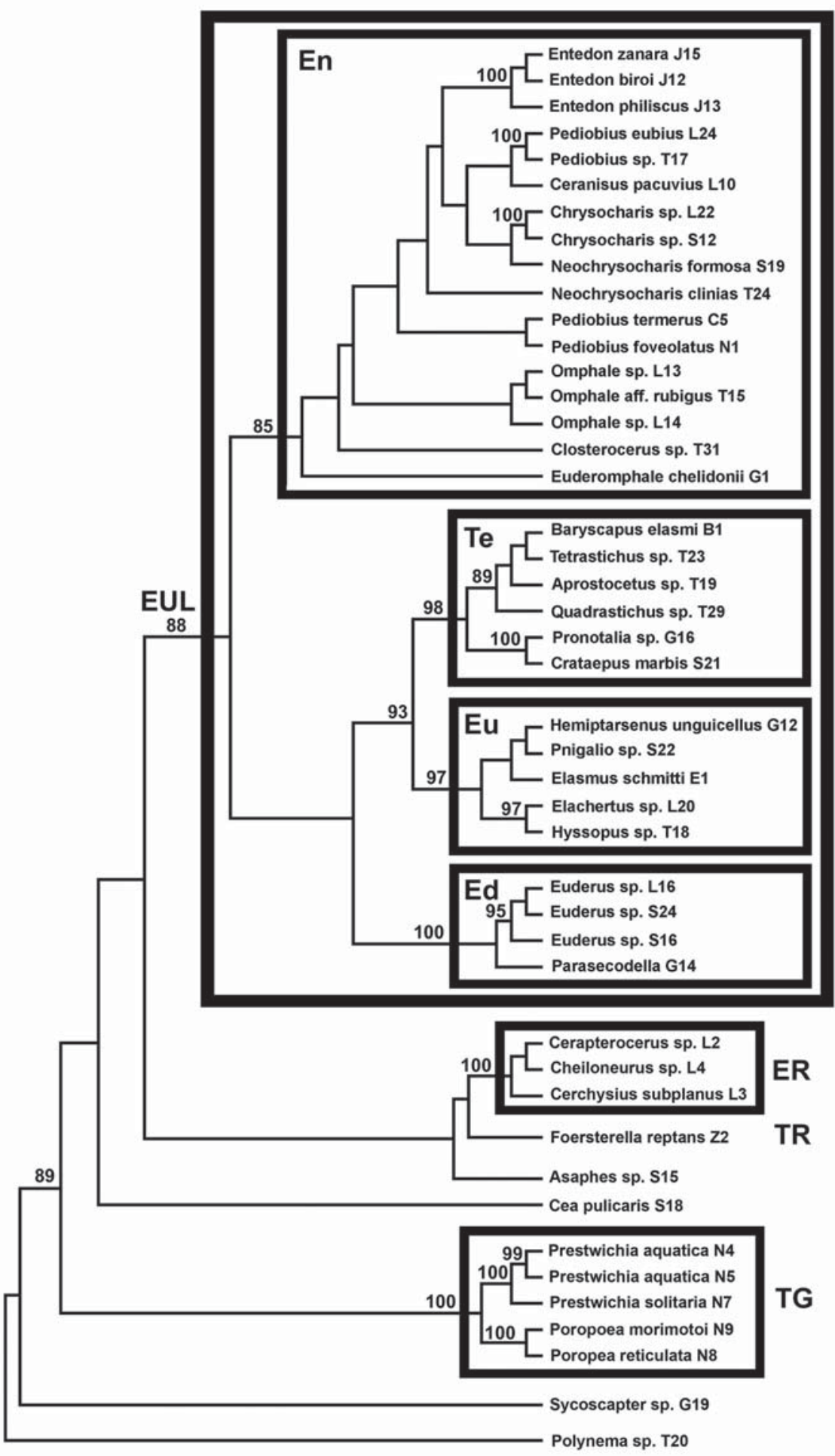

Fig. 1. Tree resultant from maximum parsimony analysis (MP) with a posteriori weighting of characters according to their retention indices (RI), numbers above branches indicate bootstrap support values; abbreviations for marked monophyletic entities: EUL Eulophidae; Eu - Eulophinae; En — Entedoninae; Te — Tetrastichinae; Ed — Entiinae (= Euderinae); ER — Encyrtidae; TR Tetracampidae; TG - Trichogrammatidae.

Рис. 1. Дерево, полученное в результате анализа по алгоритму максимальной парсимонии с последующим взвешиванием признаков в соответствии с их индексами удержания (RI), числа над ветвями обозначают показатели бутстрэппинга; условные обозначения монофилетических групп: EUL - Eulophidae; Eu - Eulophinae; En — Entedoninae; Te - Tetrastichinae; Ed — Entiinae (= Euderinae); ER — Encyrtidae; TR — Tetracampidae; TG — Trichogrammatidae. 


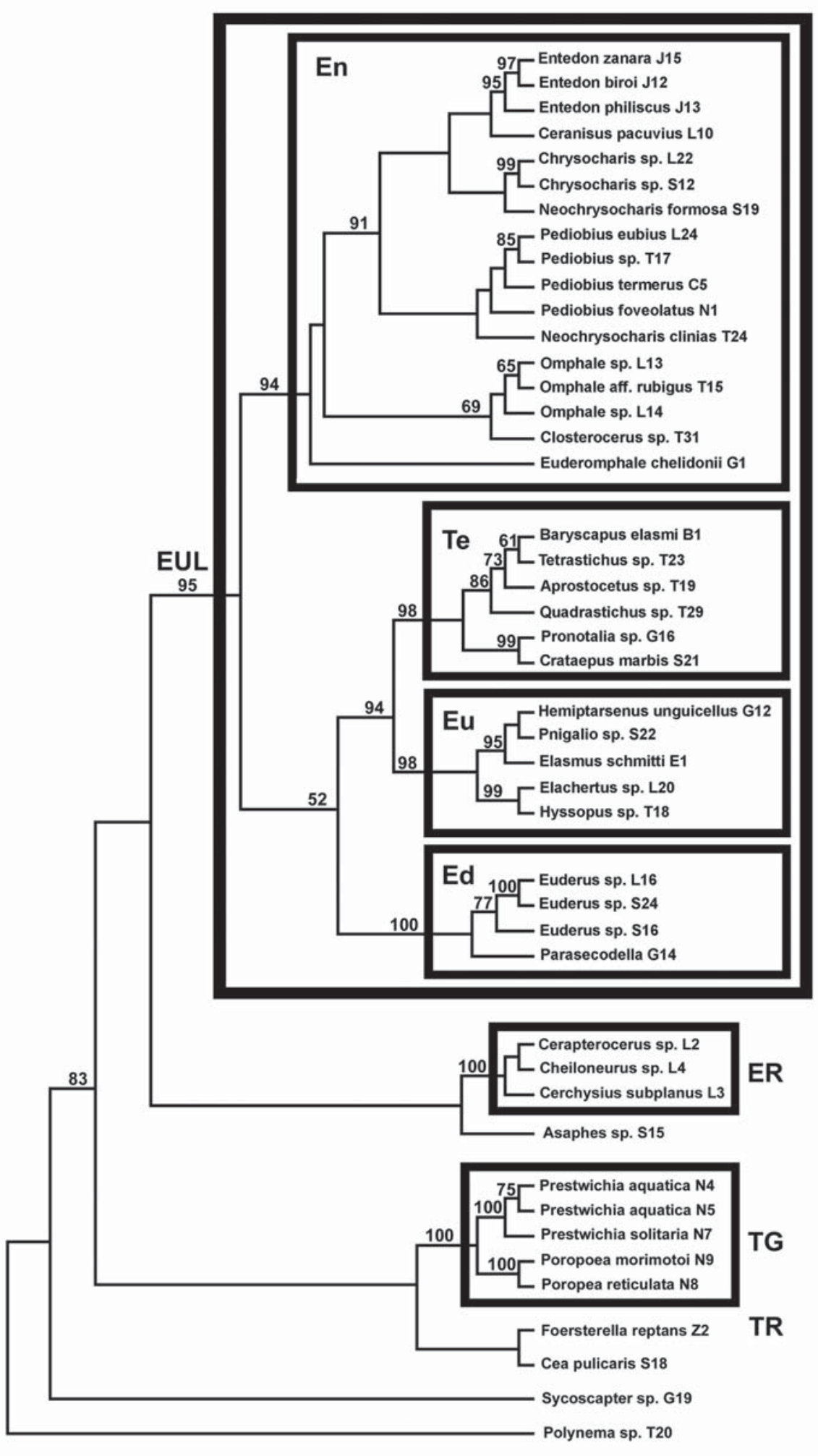

Fig. 2. Tree resultant from maximum likelihood analysis (ML); numbers above branches indicate bootstrap support values, abbreviations as in Fig. 1.

Рис. 2. Дерево, полученное в результате анализа по алгоритму максимального правдоподобия (ML); числа над ветвями обозначают показатели бутстрэппинга; условные обозначения как на рис. 1. 


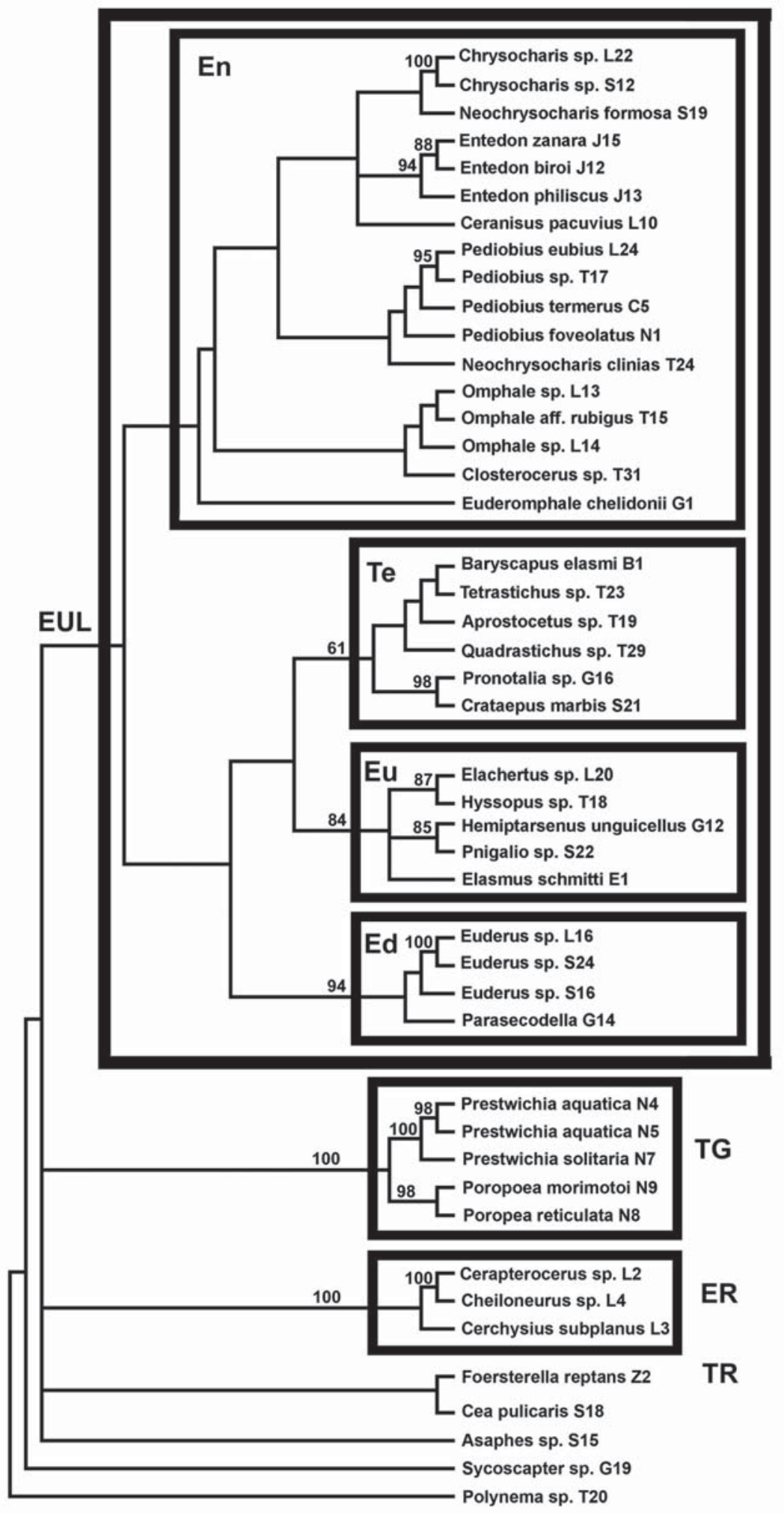

Fig. 3. The tree resultant from Bayesian analysis (BA); numbers above branches indicate bootstrap support values, abbreviations as in Fig. 1.

Рис. 3. Дерево, полученное в результате анализа по алгоритму Байесовского распределения (ВА); числа над ветвями обозначают показатели бутстрэппинга; условные обозначения как на рис. 1. 

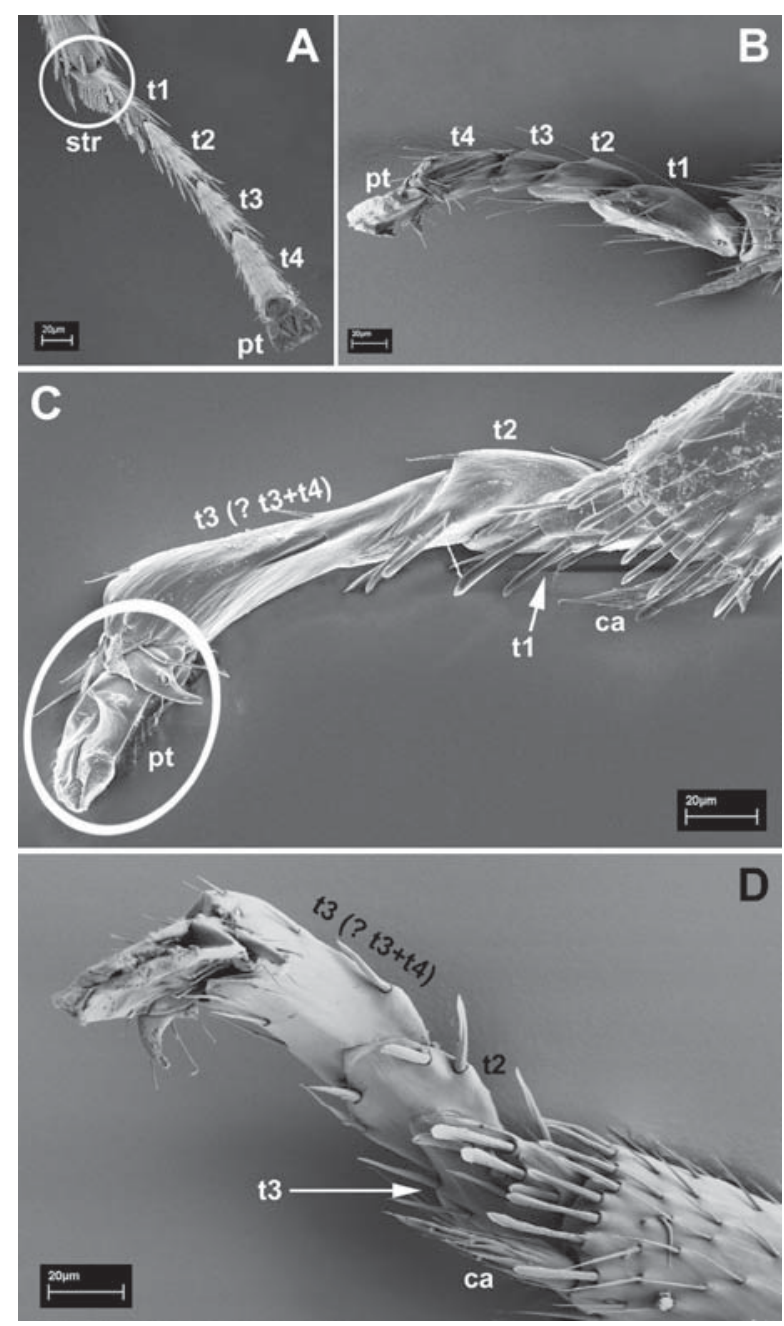

Fig. 4. Legs of Eulophidae: A - Euderus sp. (Entiinae): the strigil (str) is circled and also shown on Fig. 5B (enlarged); B-D Melittobia acasta (Walker) (Tetrastichinae), male: B - mid leg, C-D - fore leg; t1-t4 - tarsal segments; pt — pretarsus.

Рис. 4. Ноги Eulophidae: A - Euderus sp. (Entiinae): стригил (str) показан в круге и изображен в увеличенном виде на рис. 5B; В-D - Melittobia acasta (Walker) (Tetrastichinae), самец: В - средняя нога, C-D - передняя нога; t1-t4 членики лапки; $\mathrm{pt}$ - претарсус.

odes Delvare et LaSalle, 2000. The males of the tetrastichine genus Melittobia Westwood, 1847 also have only 3-segmented fore tarsi (Figs 4C, D), whereas other tarsi are 4-segmented in other eulophids (Fig. 4B).

Structure of strigil. Foretibial spur (calcar) and basitarsal comb constitute the so-called strigil, an antenna cleaner in Hymenoptera [Basibuyuk, Quicke, 1995].

Calcar. Short and straight calcar is shared by Eulophidae, Tetracampinae (Tetracampidae), Trichogrammatidae and some other groups (e.g. Calesinae) (Figs 5B-F). In other Chalcidoidea that belong to the socalled "mymarid" and "pteromalid" lineages the calcar is long (at least if compared with the breadth of fore tibia) and curved (Fig. 5A). The tip of the calcar in Eulophidae is sometimes bifid (Entedoninae, Entiinae,
Figs 5B,C) or evenly acute (Eulophinae, Tetrastichinae except for Aprostocetus Westwood, 1833, Figs 5D-F), its surface can be either nearly smooth (Fig. 5C) or covered with scales or spines (Figs 5D-F). In other members of the "eulophid lineage" the shape of the calcar also varies; e.g. the calcar is bifid in Tetracampinae, but it is evenly acute or totally reduced in Trichogrammatidae. Since the majority of Chalcidoidea (including putatively basal Mymaridae, Fig. 5A) and other groups of Hymenoptera have bifid calcar [Basibuyuk, Quicke, 1995], the evenly acute calcar can be considered as an apomorphy of certain taxa.

Basitarsal comb. In most Chalcidoidea, a comb of enlarged flattened and robust setae stretches along the lower margin of the fore basitarsus (Fig. 5A). Unlike those chalcidoids, Eulophidae, Tetracampinae and Trichogrammatidae have an oblique or reduced basitarsal comb (Figs 5B-F). The basitarsal comb is absent in Entedoninae (Fig. 5C).

\section{Antennae}

Reduced number of segments. The antenna of most eulophids has 1 to 3 rather narrow anelli, 3 to 4 funicular segments and 2- or 3-segmented club. Occasionally, the terminal anellus can be confused with the first funicular segment (e.g. in the genera Derostenus Westwood, 1833 and Mestocharis Förster, 1878 of the subfamily Entedoninae). In those cases, the true first funicular segment can be recognized by having multiporous plate sensilla [Schauff, 1991], while the anellus lacks them regardless of the size. Species of the tribe Euderomphalini have the reduced number of funicular segments (up to one) and enlarged club, what makes their antennae somewhat similar to those of Trichogrammatidae.

Sensory area on the male scape. The structure of this area is likely to support monophyly of the two subfamilies, Tetrastichinae and Entedoninae. In the males of the subfamily Tetrastichinae, the sensory area is a relatively short raised plaque on the ventral surface of the scape [Graham, 1987; Gauthier et al., 2000]. However, in Entedoninae the sensory area looks like a row of sensilla stretching along the entire ventral margin of the scape [Schauff, 1991]. Nevertheless, the sensory area is of different structure in Eulophinae and Entiinae. Arrangement of the sensilla on the scape is relatively stable in Entedoninae and Tetrastichinae, although there are some exceptions. For example, the males of the entedonine genus Parzaommomyia Girault, 1915 have the sensory plaque similar to that of Tetrastichinae [Gumovsky, Ubaidillah, 2002]. Species of both subfamiles with the expanded and modified scape, e.g., the entedonine genus Euderomphale Girault, 1916 and the tetrastichine genus Melittobia, do not have rows or plaques of any kind.

\section{Thorax}

Prothoracic spiracle. Gumovsky [2002] suggested that the position of the prothoracic spiracles is a character with a very distinctive distribution within Eu- 

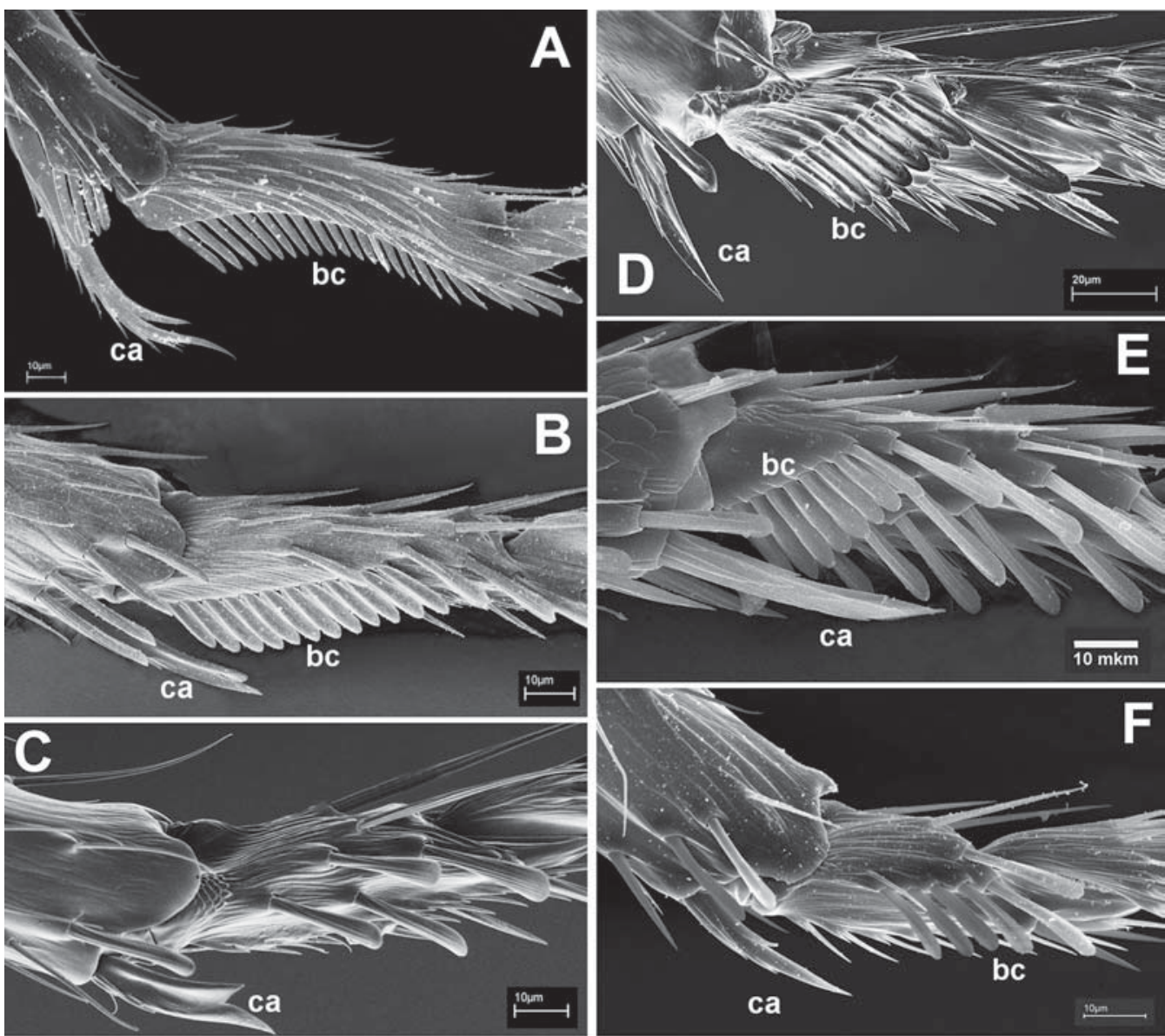

Fig. 5. Strigil of Chalcidoidea: A - Gonatocerus turberculifemur (Ogloblin) (Mymaridae); B-C - Eulophidae: B — Euderus sp. (Entiinae); C - Mestocharis maculata (Förster) (Entedoninae); D - Euplectrus bicolor (Swederus) (Eulophidae: Eulophinae); E Elasmus sp. aff. nudus (Nees) (Eulophidae: Eulophinae); F - Leptocybe invasa Fisher et LaSalle (Eulophidae: Tetrastichinae); ca calcar of fore leg; bc - basitarsal comb.

Рис. 5. Стригил Chalcidoidea: A — Gonatocerus tuberculifemur (Ogloblin) (Mymaridae); B-C — Eulophidae: B - Euderus sp. (Entiinae); C - Mestocharis maculata (Förster) (Entedoninae); D - Euplectrus bicolor (Swederus) (Eulophidae: Eulophinae); E Elasmus sp. aff. nudus (Nees) (Eulophidae: Eulophinae); F — Leptocybe invasa Fisher et LaSalle (Eulophidae: Tetrastichinae); ca шпора передней ноги; bc - гребень базитарзуса.

lophidae: the spiracles are concealed behind the lateral panel of the pronotum in Entedoninae (Fig. 6F) and exposed in three other subfamilies (Figs 6C-E). Many other chalcid families include taxa with both exposed and concealed spiracles, and the character is generally stable at least at the genus level (Figs 6A, B).

Prepectus. One of the putative morphological synapomorphies of Eulophidae is the relaively large prepectus, although it is difficult to distinguish formally this family from other Chalcidoidea by this character. In Eulophidae, the prepectus generally occupies wider area of lateral mesosoma than in other groups (Fig. 6). However, the phylogenetic value of this chatacter remains ambiguous due to some exceptions (e.g. Euderomphale and other euderomphalines).

\section{Head}

Lower margin of clypeus. Gumovsky [2002] suggested that an emargination of the lower margin of clypeus is the character state shared by Entiinae (Fig. 7C) and the tribe Euderomphalini of Entedoninae (Fig. 7D). The outgroup taxa with the reduced number of tarsal segments (e.g. Rotoitidae, Tetracampinae, some Trichogrammatidae) often also have a similar emargination. This suggests a plesiomorphic nature of this character state within the "eulophid lineage". In the subfamily Tetrastichinae, the lower margin of clypeus bilobed (another putative synapomorphy of this group). The vast majority of tetrastichines (with a few exceptions, e.g. species of Tamarixia Mercet, 1924, and some other genera) also have somewhat bilobed margin of the clypeus (Figs 7E, F). However, in the subfamily Eulophinae (the sister group to Tetrastichinae) the anterior margin of clypeus is generally straight (Fig. 7A), as well as in the subfamily Entedoninae (Fig. 7B), with a few exceptions (e.g. in the eulophine genera Dimmockia Ashmead, 1904 and Trichospilus Ferričre, 1930). This emphasizes the importance of the 


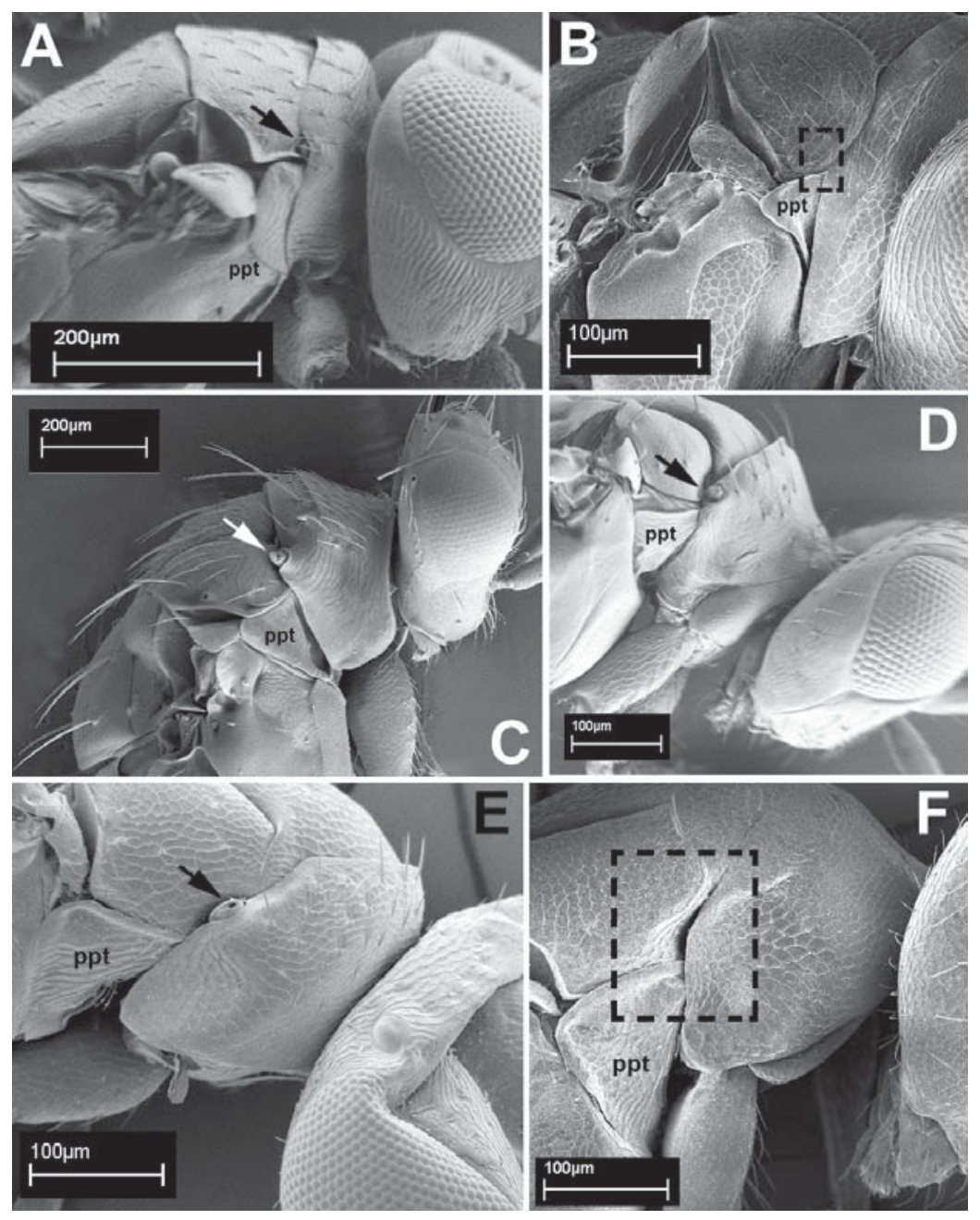

Fig. 6. Anterior mesosoma of Chalcidoidea: A - Cerapterocerus mirabilis Westwood (Encyrtidae); B - Pachyneuron sp. (Pteromalidae); C - Euplectrus bicolor (Swederus) (Eulophidae, Eulophinae); D - Aprostocetus sp. (Eulophidae, Tetrastichinae); E - Euderus sp. (Eulophidae, Entiinae); F — Neochrysocharis sp. (Eulophidae, Entedoninae); ppt — prepectus; arrow indicates exposed prothoracic spiracle, dashed frame indicates area of concealed prothoracic spiracle.

Рис. 6. Передняя часть мезосомы Chalcidoidea: A - Cerapterocerus mirabilis Westwood (Encyrtidae); B — Pachyneuron sp. (Pteromalidae); C - Euplectrus bicolor (Swederus) (Eulophidae, Eulophinae); D - Aprostocetus sp. (Eulophidae, Tetrastichinae); E Euderus sp. (Eulophidae, Entiinae); F — Neochrysocharis sp. (Eulophidae, Entedoninae); ppt, препектус; стрелка указывает на неприкрытое переднегрудное дыхальце, пунктирная рамка обозначает область переднегрудного дыхальца, прикрытого боковой панелью переднеспинки.

future studies of functional and comparative morphology of the clypeus and adjacent structures (labrum and labio-maxillary complex) for estimation of the phylogenetic value of this character.

\section{Conclusions}

The analyses of the original data set combined of a single nuclear and two mitochondrial genes, and run by three different algorithms suggest monophyly of the family Eulophidae that contains four conventional subfamilies, namely, Eulophinae, Tetrastichinae, Entiinae and Entedoninae. The results obtained, however, did not resolve any relationships of Eulophidae with the other families of Chalcidoidea.
Each of the above mentioned subfamilies is also supported as monophyletic, and the subfamilies Eulophinae (including the genus Elasmus) and Tetrastichinae appear as sister groups, therefore confirming the results obtained by Campbell et al. [2000] and Gauthier et al. [2000]. Members of the subfamily Entedoninae clustered together as a sister group to the rest of the subfamilies. However, low bootstrap support suggests that further studies are needed either to support or to disprove this pattern. The monophyly of Entedoninae is supported by the concealed prothoracic spiracles (contrary to exposed spiracles of other eulophids) and the reduced comb of fore basitarsus.

The distribution of the character states of the strigil supports the pattern obtained through the analyses of the molecular data set. Members of the subfamilies 

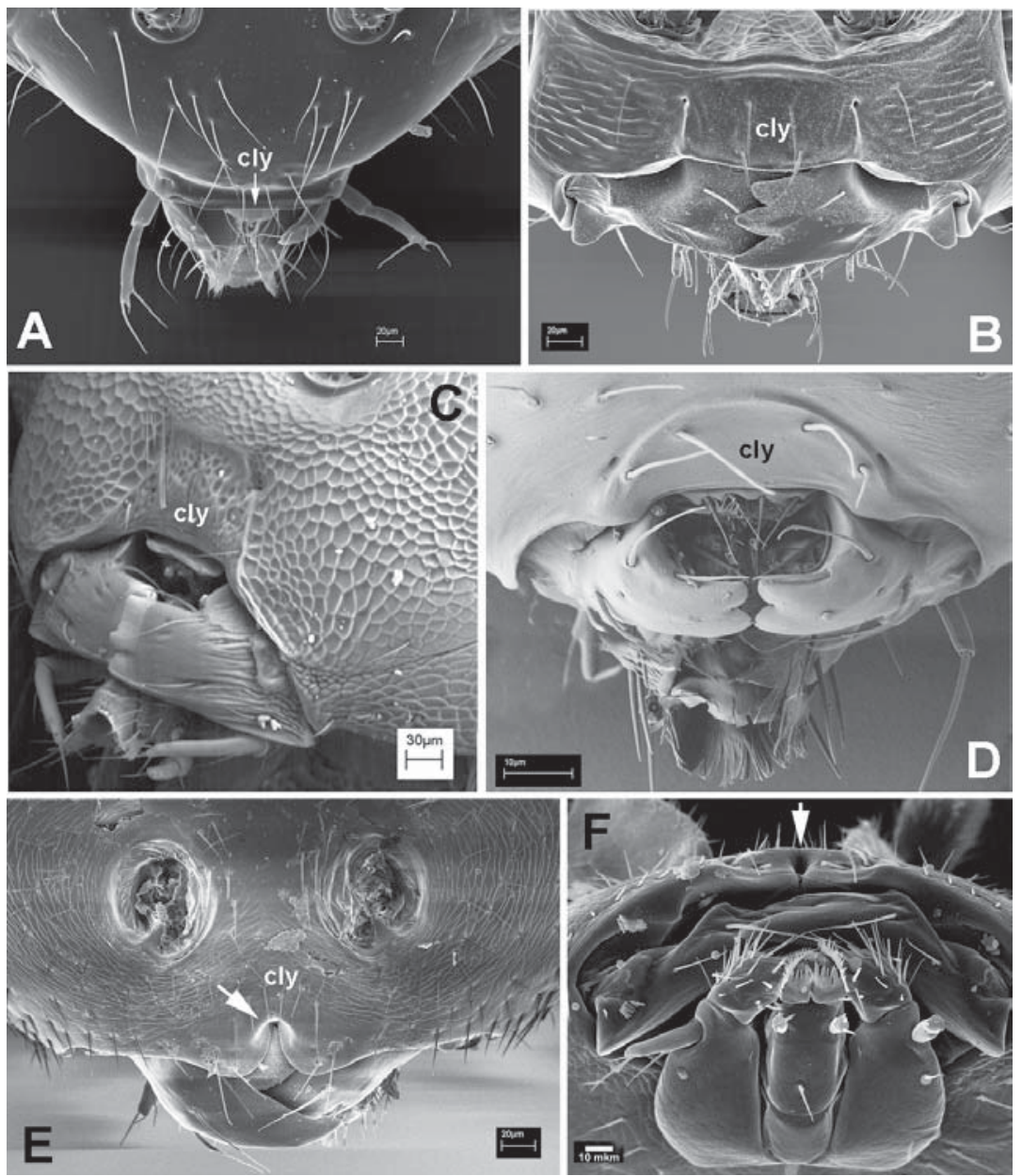

Fig. 7. Lower face of Eulophidae: A - Euplectrus bicolor (Swederus) (Eulophinae); B - Omphale lugens (Nees) (Entedoninae); C Euderus rugosus (Crawford) (Entiinae); D - Euderomphale chelidonii Erdös (Entedoninae: Euderomphalini); E, F — Melittobia acasta (Walker) (Tetrastichinae): E - lower face of male in frontal view; F - lower face of female in ventral view; cly - clypeus; arrow indicates incision on lower margin of clypeus.

Рис. 7. Нижняя часть лица Eulophidae: A - Euplectrus bicolor (Swederus) (Eulophinae); B — Omphale lugens (Nees) (Entedoninae); C - Euderus rugosus (Crawford) (Entiinae); D - Euderomphale chelidonii Erdös (Entedoninae: Euderomphalini); E, F Melittobia acasta (Walker) (Tetrastichinae): E — нижняя часть лица самца, вид спереди; F — нижняя часть лица самки, вид снизу; cly — наличник; стрелка указывает на выемку на переднем крае наличника.

Eulophinae and Tetrastichinae share evenly acute calcar, whereas Entedoninae and Entiinae have a bifid calcar that is characteristic of most other Hymenoptera. The oblique basitarsal comb (also shared by many groups of the "eulophid lineage") is present in all subfamilies, except for the Entedoninae.

The subfamily Tetrastichinae is monophyletic in all trees, and the bilobed anterior margin of clypeus can be considered as a putative synapomorphy of this group.

\section{ACKNOWLEDGEMENTS}

This study was supported by the grants from the SYNTHESYS Project (GB-TAF-535), the author's return fellowship grant from the Alexander von Humboldt Foundation (Germany) and from the State Fund of Fundamental Research, Ukraine (SFFR, F35/002). The author thanks John Noyes, Paul Ready and Johann
Ingle for their general assistance during his visit to the BMNH, Chao-Dong Zhu (Institute of Zoology, Chinese Academy of Sciences, Beijing) for his help with molecular studies, Stanislav Gorb (University of Kiel, Kiel, Germany) for his assistance and useful advice during the author's fellowship at MPI, Victor Fursov (I.I. Schmalhausen Institute of Zoology, Kiev) for providing specimens of Trichogrammatidae and Serguei Triapitsyn (University of California, Riverside, USA) for providing specimens of Gonatocerus tuberculifemur used in this research.

\section{References}

Basibuyuk H.H., Quicke D.L.J. 1995. Morphology of the antenna cleaner in the Hymenoptera with particular reference to nonaculeate families (Insecta) // Zoologica Scripta. Vol.24. P.157177. 
Bouček Z. 1988. Australasian Chalcidoidea (Hymenoptera). A biosystematic revision of genera of fourteen families, with a reclassification of species. Wallingford, U.K.: CAB International. $832 \mathrm{pp}$.

Campbell B.C., Steffen-Campbell J.D., Werren J.H. 1993. Phylogeny of the Nasonia species complex (Hymenoptera: Pteromalidae) inferred from an internal transcribed spacer (ITS2) and 28S rDNA sequences // Insect Molecular Biology. Vol.2. P.225237.

Campbell B., Heraty J., Rasplus J.-Y., Chan K., Steffen-Campbell J., Babcock C. 2000. Molecular systematics of the Chalcidoidea using 28S-D2 rDNA // Austin A.D., Dowton M. (eds) Hymenoptera: evolution, biodiversity and biological control. Collingwood. P.59-73.

Desjardins C.A., Regier J.C., Mitter C. 2007. Phylogeny of pteromalid parasitic wasps (Hymenoptera: Pteromalidae): Initial evidence from four protein-coding nuclear genes // Molecular Phylogenetics and Evolution. Vol.45. No.2. P.454-469.

Douady C.J., Delsuc F., Boucher Y., Doolittle W.F., Douzery E.J. 2003. Comparison of Bayesian and maximum likelihood bootstrap measures of phylogenetic reliability // Molecular Biology and Evolution. Vol.20. P. 248-254.

Gauthier N., LaSalle J., Quicke D.L.J., Godfray H.C.J. 2000. Phylogeny of Eulophidae (Hymenoptera: Chalcidoidea), with a reclassification of Eulophinae and the recognition that Elasmidae are derived eulophids // Systematic Entomology. Vol.25. P.521-539.

Gibson G.A.P. 1986. Evidence for monophyly and relationships of Chalcidoidea, Mymaridae, and Mymarommatidae (Hymenoptera: Terebrantes) // Canadian Entomologist. Vol.118. No.3. P. 205-240.

Gibson G.A.P. 1999. Sister-group relationships of the Platygastroidea and Chalcidoidea (Hymenoptera): an alternate hypothesis to Rasnitsyn (1988) // Zoologica Scripta. Vol.28. No.1-2. P.125-138.

Gibson G.A.P., Heraty J.M., Woolley J.B. 1999. Phylogenetics and classification of Chalcidoidea and Mymarommatoidea - a review of current concepts (Hymenoptera, Apocrita) // Zoologica Scripta. Vol. 28. No.1-2. P.87-124.

Gibson G.A.P., Huber J.T., Woolley J.B. (eds). 1997. Annotated Keys to the Genera of Nearctic Chalcidoidea (Hymenoptera) Ottawa: National Research Council Research Press. 794 pp.

Gladun D., Gumovsky A. 2006. The pretarsus in Chalcidoidea (Hymenoptera Parasitica): functional morphology and possible phylogenetic implications // Zoologica Scripta. Vol.35. No.6. P.607-626.

Gokhman V.E. 2004. Karyotypes of parasitic wasps of the family Eulophidae (Hymenoptera): new data and review // Russian Entomol. J. Vol.13. No.3. P.71-74.

Gokhman V.E. 2009. Karyotypes of parasitic Hymenoptera. Dordrecht: Springer. 183 pp.

Gokhman V.E., Gumovsky A.V. 2009. Main trends of karyotype evolution in the superfamily Chalcidoidea (Hymenoptera) // Comparative Cytogenetics. Vol.3. No.1. P.63-69.

Goolsby J.A., Burwell C.J., Makinson J., Driver F. 2001. Investigation of the biology of the hymenoptera associated with Fergusonina sp. (Diptera: Fergusoninidae) a gall fly of Melaleuca quinquenervia integrating molecular techniques // Journal of Hymenoptera Research. Vol.10. No.2. P.163-180.

Graham M.W.R. de V. 1987. A reclassification of the European Tetrastichinae (Hymenoptera: Eulophidae), with a revision of certain genera // Bulletin of the British Museum (Natural History), Entomological Series. Vol.55. 392 pp.
Gumovsky A. 2002. Monophyly and preliminary phylogeny of Entedoninae (Hymenoptera, Chalcidoidea, Eulophidae): 28S D2 rDNA considerations and morphological support // Melika G., Thuróczy Cs. (eds). Parasitic Wasps: Evolution, Systematics, Biodiversity and Biological Control Budapest: Agroinform. P.193-219.

Gumovsky A., Ubaidillah R. 2002. Revision of the genus Parzaommomyia Girault (Hymenoptera: Eulophidae), with taxonomic notes on related genera // Zoologische Mededelingen. Vol.76. No.9. P.65-102.

Hall T.A. 1999. BioEdit: a user-friendly biological sequence alignment editor and analysis program for Windows 95/98/NT // Nucleic Acids Symposium Series. Vol.41. P.95-98.

Hansson C., Straka J. 2009. The name Euderinae (Hymenoptera: Eulophidae) is a junior homonym // Proceedings of the Entomological Society of Washington. Vol.111. P.272-273.

Harry M., Solignac M., Lachaise D. 1996. Adaptive radiation in the Afrotropical region of the Paleotropical genus Lissocephala (Drosophilidae) on the pantropical genus Ficus (Moraceae) // Journal of Biogeography. Vol.23. P.543-552.

Murphy S.T., La Salle J. 1999. Balancing biological control strategies in the IPM of New World invasive Liriomyza leafminers in field vegetables crops // Biocontrol News and Information. Vol.20. P.91-104.

Noyes J.S. 1990. A word on chalcidoid classification // Chalcid Forum. Vol.13. P. 6-7.

Noyes J.S. 2004. Universal Chalcidoidea Database. http:// www.nhm.ac.uk/entomology/chalcidoids/index.html

Page R.D.M. 1996. TREEVIEW: An application to display phylogenetic trees on personal computers // Computer Applications in the Biosciences. Vol.12. P.357-358.

Pons J. 2006. DNA-based identification of preys from non-destructive, total DNA extractions of predators using arthropod universal primers // Molecular Ecology Notes. Vol.6. No.3. P.623626.

Posada D. 2008. jModelTest: Phylogenetic Model Averaging // Molecular Biology and Evolution. Vol.25. P.1253-1256.

Ronquist F., Rasnitsyn A.P., Roy A., Eriksson K., Lindgren M. 1999. Phylogeny of the Hymenoptera: A cladistic reanalysis of Rasnitsyn's (1988) data // Zoologica Scripta. Vol.28. No.1-2. P.13-50.

Ronquist F., Huelsenbeck J. P. 2003. MRBAYES 3: Bayesian phylogenetic inference under mixed models // Bioinformatics. Vol.19. P.1572-1574.

Schauff M.E. 1991. The Holarctic genera of Entedoninae (Hymenoptera: Eulophidae) // Contributions of the American Entomological Institute. Vol.26. $109 \mathrm{pp}$.

Simon C., Frati F., Beckenbach A., Crespi B., Liu H., Flook P. 1994. Evolution, weighting and phylogenetic utility of mitochondrial gene sequences and a compilation of conserved polymerase chain reaction primers // Annals of the Entomological Society of America. Vol.87. P.651-701.

Swofford D.L. 1998. PAUP*. Phylogenetic Analysis Using Parsimony (*and Other Methods). Version 4. Sinauer Associates, Sunderland, Massachusetts.

Thompson J.D., Higgins D.G., Gibson T.J. 1994. CLUSTAL W: improving the sensitivity of progressive multiple sequence alignment through sequence weighting, positions-specific gap penalties and weight matrix choice // Nucleic Acids Research. Vol.22. P 4673-4680.

Waterhouse D.F., Norris K.R. 1987. Biological Control: Pacific Prospects. Melborne: Ikata Press. 454 pp. 
Appendix 1. Taxa included in the analysis.

Приложение 1. Таксоны, включенные в анализ.

\begin{tabular}{|c|c|c|}
\hline $\begin{array}{l}\text { Number } \\
\text { (extract } \\
\text { code) }\end{array}$ & Species & Label data \\
\hline \multicolumn{3}{|c|}{ Eulophidae } \\
\hline $\mathrm{J} 15$ & Entedon zanara Walker, 1839 & $\begin{array}{l}\text { Germany: Stuttgart, ex Cionus sp. (Coleoptera: Curculionidae), } \\
\text { VIII.2004 (Gumovsky) }\end{array}$ \\
\hline $\mathrm{J} 12$ & E. biroi Erdös, 1944 & Bulgaria: Rhodope Mountains, VI.2001 (Stojanova) \\
\hline $\mathrm{J} 3$ & E. philiscus Walker, 1851 & Ukraine: Kiev, Lysa Hora range, VI.2004 (Gumovsky) \\
\hline L10 & Ceranisus pacuvius (Walker, 1838) & $\begin{array}{l}\text { Ukraine: Kiev, between Khodoseevka and Gvozdov, VI.2004 } \\
\text { (Gumovsky) }\end{array}$ \\
\hline L22 & Chrysocharis sp. & Ukraine: Kiev, Lysa Hora range, VI.2004 (Gumovsky) \\
\hline \multicolumn{3}{|c|}{ Eulophidae } \\
\hline S12 & Chrysocharis sp. & $\begin{array}{l}\text { Ukraine: Kiev, between Khodoseevka and Gvozdov, VI.2004 } \\
\text { (Gumovsky) }\end{array}$ \\
\hline S19 & $\begin{array}{l}\text { Neochrysocharis formosa (Westwood, } \\
1833 \text { ) }\end{array}$ & Ukraine: Kiev, Trukhanov Island, VI.2001 (Gumovsky) \\
\hline $\mathrm{L} 24$ & Pediobius eubius (Walker, 1839) & Ukraine: Kiev, Lysa Hora range, VI.2004 (Gumovsky) \\
\hline $\mathrm{C} 5$ & P. termerus (Walker, 1839) & Germany: Stuttgart, VII.2004 (Gumovsky) \\
\hline T17 & Pediobius $\mathrm{sp}$. & Germany: Stuttgart, VIII.2004 (Gumovsky) \\
\hline N1 & P. foveolatus (Crawford, 1912) & $\begin{array}{l}\text { Ethiopia: ex pupa of Epilachna sp. (Coleoptera: Coccinelidae), } \\
\text { I.2005 }\end{array}$ \\
\hline $\mathrm{T} 24$ & $\begin{array}{l}\text { Neochrysocharis clinias (Walker, } \\
1838 \text { ) }\end{array}$ & Ukraine: Kiev, Trukhanov Island, VI.2001 (Gumovsky) \\
\hline L13 & Omphale sp. & Ukraine: Kiev, Lysa Hora range, VI.2004 (Gumovsky) \\
\hline L14 & Omphale sp. & Ukraine: Kiev, Lysa Hora range, VI.2004 (Gumovsky) \\
\hline T15 & $\begin{array}{l}\text { Omphale sp. aff. rubigus (Walker, } \\
\text { 1839) }\end{array}$ & Germany: Stuttgart, V.2004 (Gumovsky) \\
\hline T31 & Closterocerus sp. & Ukraine: Kiev, Trukhanov Island, VI.2001 (Gumovsky) \\
\hline G1 & $\begin{array}{l}\text { Euderomphale chelidonii Erdös, } \\
1966\end{array}$ & $\begin{array}{l}\text { Ukraine: Kiev, Solomenka, ex Aleyrodes proletella (Heteroptera: } \\
\text { Aleyrodidae), VII.2004 (Gumovsky) }\end{array}$ \\
\hline B1 & Baryscapus elasmi (Graham, 1986) & $\begin{array}{l}\text { Ukraine: Kherson Province, ex Polistes (Hymenoptera: Vespidae) } \\
\text { nest, VI. } 2003 \text { (Rusina) }\end{array}$ \\
\hline T19 & Aprostocetus sp. & Germany: Stuttgart, VIII.2004 (Gumovsky) \\
\hline $\mathrm{T} 23$ & Tetrastichus sp. & Ukraine: Kiev, Trukhanov Island, VI.2001 (Gum \\
\hline T29 & Quadrastichus sp. & Germany: Stuttgart, VIII.2004 (Gumovsky) \\
\hline G16 & Pronotalia sp. & Ukraine: Crimea, ex Cirsium, VII.2004 (Gumovsky) \\
\hline $\mathrm{S} 21$ & Crataepus marbis (Walker, 1839) & Germany: Stuttgart, VIII.2004 (Gumovsky) \\
\hline G12 & $\begin{array}{l}\text { Hemiptarsenus unguicellus } \\
\text { (Zetterstedt, 1838) }\end{array}$ & $\begin{array}{l}\text { Ukraine: Kiev, between Khodoseevka and Gvozdov, VI.2004 } \\
\text { (Gumovsky) }\end{array}$ \\
\hline S22 & Pnigalio sp. & Germany: Stuttgart, VIII.2004 (Gumovsky) \\
\hline E1 & Elasmus schmitti (Ruschka, 1920) & Ukraine: Kherson Province, ex Polistes nest, VI.2003 (Rusina) \\
\hline L20 & Elachertus sp. & Ukraine: Kiev, Park Druzhby Narodiv, 03.VI.2004 (Gumovsky) \\
\hline T18 & Hyssopus sp. & Germany: Stuttgart, VIII.2004 (Gumovsky) \\
\hline L16 & Euderus sp. & Ukraine: Kiev, Lysa Hora range, VI.2004 (Gumovsky) \\
\hline S24 & Euderus sp. & Ukraine: Kiev, Lysa Hora range, VI.2004 (Gumovsky) \\
\hline S16 & Euderus sp. & Ukraine: Kiev: Karavayevy Dachi range, VI.2004 (Gumovsky) \\
\hline G14 & Parasecodella sp. & $\begin{array}{l}\text { Ukraine: Kiev, between Khodoseevka and Gvozdov, VI.2004 } \\
\text { (Gumovsky) }\end{array}$ \\
\hline \multicolumn{3}{|r|}{ (3) } \\
\hline S18 & Cea pulicaris Walker, 1837 & Ukraine: Kiev, Lysa Hora range, VI.2004 (Gumovsky) \\
\hline S15 & Asaphes sp. & $\begin{array}{l}\text { Ukraine: Kiev, between Khodoseevka and Gvozdov, VI.2004 } \\
\text { (Gumovsky) }\end{array}$ \\
\hline G19 & Sycoscapter sp. & $\begin{array}{l}\text { Japan: Tokushima, Itano, Jogamaru pond, 20.VII.2004, ex Ficus } \\
\text { (Fursov, Yamagishi) }\end{array}$ \\
\hline \multicolumn{3}{|c|}{ Mymaridae } \\
\hline $\mathrm{T} 20$ & Polynema sp. & Ukraine: Kiev, Lysa Hora range, VI.2004 (Gumovsky) \\
\hline
\end{tabular}




\begin{tabular}{|c|c|c|}
\hline $\begin{array}{l}\text { Number } \\
\text { (extract } \\
\text { code) }\end{array}$ & Species & Label data \\
\hline \multicolumn{3}{|c|}{ Trichogrammatidae } \\
\hline N4 & $\begin{array}{l}\text { Prestwichia aquatica Lubbock, } 1864 \\
\text { (winged) }\end{array}$ & $\begin{array}{l}\text { Russia: St. Petersbourg, Novyi Peterhof, ex egg of Agabus sp. } \\
\text { (Coleoptera: Dytiscidae) in stem of Sagittaria, 14.VIII.2004 } \\
\text { (Fursov) }\end{array}$ \\
\hline N5 & P. aquatica (wingless) & $\begin{array}{l}\text { Ukraine: Kiev, Pusha-Voditsa, ex egg of Cybister sp. } \\
\text { (Coleoptera: Dytiscidae) on Alisma, 26.VI.2003, (Fursov) }\end{array}$ \\
\hline N7 & P. solitaria Ruschka, 1913 (winged) & $\begin{array}{l}\text { Ukraine: Kiev, Pusha-Voditsa, ex egg of damselfly (Odonata), } \\
\text { 26.06.2003 (Fursov) }\end{array}$ \\
\hline N8 & Poropoea reticulata Hirose, 1963 & $\begin{array}{l}\text { Japan: Tsukuba, ex egg of Cycnotrachellus sp. (Coleoptera: } \\
\text { Atellabidae), 14.V.2004 (Fursov) }\end{array}$ \\
\hline N9 & P. morimotoi Hirose, 1963 & Japan: Tsukuba, 14.V.2004, on Rosa sp. (Fursov) \\
\hline \multicolumn{3}{|c|}{ Encyrtidae } \\
\hline L2 & Cerapterocerus sp. & $\begin{array}{l}\text { Ukraine: Kiev, between Khodoseevka and Gvozdov, VI.2004 } \\
\text { (Gumovsky) }\end{array}$ \\
\hline L3 & Cerchysius subplanus (Dalman, 1820) & Ukraine: Kiev, Trukhanov Island, VI.2001 (Gumovsky) \\
\hline L4 & Cheiloneurus elegans (Dalman, 1820) & Ukraine: Kiev, Trukhanov Island, VI.2001 (Gumovsky) \\
\hline \multicolumn{3}{|c|}{ Tetracampidae (Tetracampinae) } \\
\hline $\mathrm{Z} 2$ & Foersterella reptans (Nees, 1834) & $\begin{array}{l}\text { Ukraine: Kiev, between Khodoseevka and Gvozdov, VI.2004 } \\
\text { (Gumovsky) }\end{array}$ \\
\hline
\end{tabular}

